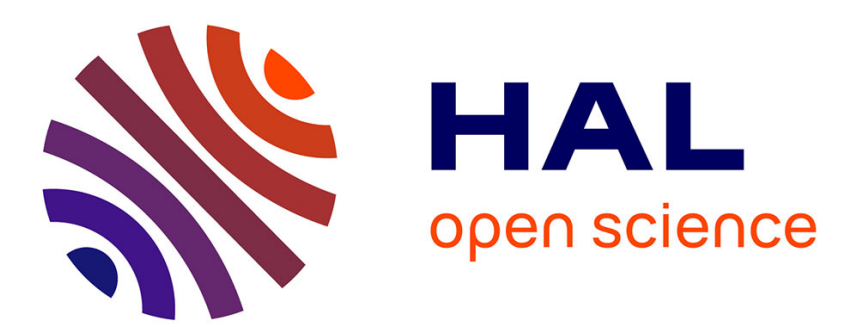

\title{
Southeast Pacific blue whale song recorded off Isla Chañaral, northern Chile
}

Julie Patris, Susannah J Buchan, Giselle Alosilla, Naysa Balcazar- Cabrera, Franck Malige, Hervé Glotin

\section{- To cite this version:}

Julie Patris, Susannah J Buchan, Giselle Alosilla, Naysa Balcazar- Cabrera, Franck Malige, et al.. Southeast Pacific blue whale song recorded off Isla Chañaral, northern Chile. Marine Mammal Science, 2020, 36 (4), pp.1339 - 1346. 10.1111/mms.12738 . hal-03199531

\section{HAL Id: hal-03199531 https://hal.science/hal-03199531}

Submitted on 16 Apr 2021

HAL is a multi-disciplinary open access archive for the deposit and dissemination of scientific research documents, whether they are published or not. The documents may come from teaching and research institutions in France or abroad, or from public or private research centers.
L'archive ouverte pluridisciplinaire HAL, est destinée au dépôt et à la diffusion de documents scientifiques de niveau recherche, publiés ou non, émanant des établissements d'enseignement et de recherche français ou étrangers, des laboratoires publics ou privés. 
2 Southeast Pacific blue whale song recorded off Isla Chañaral, Northern Chile

3

4

5

6 Authors: Julie Patris ${ }^{(1)}$, Susannah J. Buchan*(2,3,4), Giselle Alosilla ${ }^{(5)}$, Naysa Balcazar-

7 Cabrera $^{(4)}$, Franck Malige ${ }^{(1)}$, Hervé Glotin ${ }^{(1)}$

8

9 1) AMU, Université de Toulon, CNRS, LIS, Marseille, DYNI team, France

10 2) Centro de Estudios Avanzados en Zonas Áridas, Coquimbo, Chile

11 3) Center for Oceanographic Research COPAS Sur-Austral, University of Concepción,

12 Concepción, Chile

13 4) Woods Hole Oceanographic Institution, Biology Department, Woods Hole,

14 Massachusetts

15 5) Instituto de Biología, Facultad de Ciencias, Universidad de Valparaíso, Valparaíso,

16 Chile

17

$18 *$ Correspondence

19 Email: sjbuchan@gmail.com

20

21 * KEYWORDS: blue whale, migration, songs, Southeast Pacific

22

23

24

25 
27 Determining the distribution and seasonal movements of baleen whales is fundamental

28 to the development of conservation strategies and marine spatial planning, which ensure

29 their continued protection (e.g., Pompa, Ehrlich, and Ceballos (2011), Mullen, Peterson, 30 and Todd (2013), Redfern et al. (2013a, 2013b)). One method widely used to monitor

31 distribution and movements of cetaceans is Passive Acoustic Monitoring (PAM) (e.g., 32 Mellinger, Stafford, Moore, Dziak, and Matsumoto (2007), Van Parijs et al. (2009)). The

33 loud, repetitive, low-frequency songs of baleen whales make these animals particularly 34 good candidates for acoustically determining their occurrence and in turn their 35 distribution (e.g., Stafford, Nieukirk, and Fox (1999a, 1999b), Cerchio, Jacobsen, and 36 Norris (2001), Širović, Hildebrand, Wiggins, and Thiele (2009), Buchan, Hucke-Gaete, 37 Rendell, and Stafford (2015)). Endangered (https://www.iucn.org/) blue whales 38 (Balaenoptera musculus) produce distinct song types recorded in different oceanic 39 regions with largely distinct spatial and temporal distributions (e.g., McDonald, 40 Mesnick, and Hildebrand (2006) and references therein, Stafford, Chapp, Bohnenstiel, 41 and Tolstoy (2011), Samaran et al. (2013), Buchan, Hucke-Gaete, Rendell, and Stafford 42 (2014), Buchan et al. (2015), Balcazar et al. (2017)). Song in blue whales is assumed to 43 serve some reproductive function as it is believed to be produced only by males (Oleson 44 et al., 2007a) and is produced throughout the animals' migratory range (Stafford et al. 45 (1999a), Stafford, Nieukirk, and Fox (2001)). Blue whale song remains relatively stable 46 over time, although there is some intra-annual variation in song production (Oleson, 47 Wiggins, and Hildebrand, 2007b) and a decrease in the frequency of tonal song 48 components has been reported over decadal timescales (McDonald, Hildebrand, and 49 Mesnick (2009), Gavrilov, McCauley, and Gedamke (2012)). Therefore, PAM offers a 
50 very useful method to monitor the distribution of blue whale acoustic groups

51 worldwide.

52

53 The predominant song type of Southeast Pacific blue whales, known as the Southeast

54 Pacific 2, (SEP2) (Buchan et al., 2014) has been recorded in Chilean Patagonia (Buchan 55 et al., 2014, and 2015), off Juan Fernandez (Truong, Širović, Tripovich, and Rogers, 56 2016), and in the eastern Tropical Pacific (Stafford et al. (1999b), Buchan et al. (2015)).

57 This acoustic presence supports a migratory range for this group between Chilean

58 Patagonia and the eastern Tropical Pacific. This migratory range is also supported by 59 genetic sampling of the individuals within this range (Torres-Florez, Hucke Gaete, and 60 LeDuc, 2014), photo-identification (Torres-Florez et al., 2015), and studies using 61 satellite tags (Hucke-Gaete et al., 2018). Placed within the migratory corridor of south 62 Pacific blue whales, Isla Chañaral is part of the Humboldt Archipelago, a series of 63 coastal islands within the productive Humboldt Current System (Thiel et al., 2007)

64 (Figure 1). The waters surrounding Isla Chañaral, which lies 3.5 nautical miles from the 65 mainland, are a known summer feeding ground primarily for fin whales (Balaenoptera 66 physalus) (Pérez-Álvarez et al. (2006), Toro, Vilina, Capella, and Gibbons (2016), 67 Sepúlveda, Santos, and Pavez (2017), Sepúlveda, Pérez-Álvarez, and Santos-Carvallo 68 (2018)), but also blue whales, humpback whales (Megaptera novaeangliae), sei whales 69 (Balaenoptera borealis), and minke whales (Balaenoptera bonaerensis) have also been 70 sighted (Capella, Vilina, and Gibbons (1999), Sepúlveda pers. Comm.). This area has 71 long since been the focus of a Marine Protected Area proposal. The acoustic identity of 72 the blue whales that visit this area is unknown. In this study, we report the analysis of 73 new PAM data from Northern Chile to examine whether there is evidence of southeast 74 Pacific blue whales (SEP2 song type) in this area. 
76 Passive acoustic data were collected within the Isla Chañaral channel, between the Isla

77 Chañaral and the mainland, at $29^{\circ} 00^{\prime} 44^{\prime \prime} \mathrm{S}$ and $71^{\circ} 31^{\prime} 26^{\prime \prime} \mathrm{W}$ (Figure 1) during three

78 periods of two weeks in January and February 2017 (see Patris, Malige, and Glotin

79 (2017) for details). A 'BOMBYX II', which includes a Cetacean Research C57

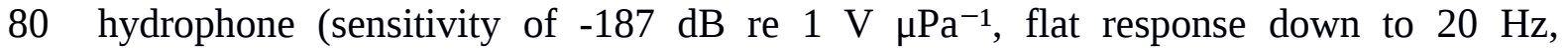

81 omnidirectional at frequencies less than $10 \mathrm{kHz}$ ), powered by a 9V source and high-pass

82 filtered $(\mathrm{C}=47 \mu \mathrm{F}$, frequency cut $0.15 \mathrm{~Hz})$ and a commercial SONY PCM-M10 recording

83 device (gain 6, Rin $=22 \mathrm{kOhm}$ ) equipped with a 256 GB memory card, set up in a

84 specialized tube made by OSEAN SA (France) able to resist high pressure, was

85 deployed between 15 and 20 m below the surface on a mooring where the maximum

86 water column depth was $70 \mathrm{~m}$. The 'BOMBYX II' was deployed by the University of

87 Toulon and CNRS (DYNI team, LIS).

88

89 Recording was done at a sample rate of $48 \mathrm{kHz}$ so as to record a vast diversity of 90 cetaceans, ranging from large whales to dolphins, and at 16-bits, allowing for high 91 sensitivity without saturating the memory ${ }^{\mathrm{i}}$. No low-pass filter (such as an anti-aliasing 92 filter) was used for this recording, since it was not considered necessary for our purpose.

93 Acoustic data were recorded between the 16 January and the 27 February 2017. No data

94 were recorded during the 30 and 31 January and during the night between the 13 and 14

95 February because of instrument redeployment.

96

97 The SEP2 song is made up of a four-unit phrase (A, B, C, D, see Figure 2) lasting $60 \mathrm{~s}$

98 that is repeated every two minutes, in long series lasting for hours. All units are long 99 and stable pulsed sounds; thus their power spectra show a set of discrete frequencies 
100 (Patris, Malige, Glotin, Asch, and Buchan, 2019). The energy of the spectra is generally 101 concentrated around the $24 \mathrm{~Hz}$ peak. Unit A has an average duration of $22 \mathrm{~s}$, unit B of $10213 \mathrm{~s}$, unit $\mathrm{C}$ of $5 \mathrm{~s}$, and unit $\mathrm{D}$ an average duration of $13 \mathrm{~s}$. Usually, not all units are 103 visible due to low signal to noise ratio (SNR) and units C and D contain most of the 104 signal's energy. In this study SEP2 song phrases were annotated whenever at least the 24

105 Hz-frequency peak of units C and D were visible. The SEP2 songs of Southeast Pacific 106 blue whales were annotated manually, i.e., a box was drawn around the C and D units of 107 the SEP2 song phrase, on the spectrogram visible in Raven Pro 1.5 (Bioacoustics 108 Research Program, 2012). The following parameters were used: 8,192 sample FFT, 50\% 109 overlap, Hann window, with a Raven scale set to view $60 \mathrm{~Hz}$ over 200 s. Herein, we 110 refer to all phrases with at least C and D units as SEP2 song phrases.

112 A nonsystematic double check of the data by another analyst showed that few phrases 113 (with only unit B visible) were not counted by the first analyst (missed detections). 114 Units C and D were not visible due to noise or propagation effects that mask low 115 frequencies. Furthermore, unit A and the pair C-D are sometimes confoundable (having 116 similar characteristics in duration and peak frequency). Thus, in some cases, unit A and 117 the pair C-D of the same phrase were counted as two distinct occurrences of a phrase 118 (false positive). As the second analysis was not systematic on all data but only on a 119 portion of it (one third), it served to evaluate the importance of errors during the 120 counting of the first analysis. Based on this double check, we estimate the error in 121 counting SEP2 occurrences to be less than 3\%.

123 A total of $913 \mathrm{~h}$ of acoustic recordings were analyzed, over which 1,981 SEP2 song 124 phrases were identified, annotated and counted by the first analyst (Figure 3). As 
125 presented in these studies, we also noted the presence of two short high frequency

126 precursors before units A (around $430 \mathrm{~Hz}$ ) and D (around $350 \mathrm{~Hz}$ ) (see Figure 2). Two

127 faint downsweeps are identified in phrases with high signal-to-noise ratio: in unit A

128 (duration of $5 \mathrm{~s}$ from $150 \mathrm{~Hz}$ to $120 \mathrm{~Hz})(n=10)$ and in unit B (duration of $12 \mathrm{~s}$ from

$129450 \mathrm{~Hz}$ to $300 \mathrm{~Hz})(n=10)$, see Figure 2. This sound may be a byproduct of the pulsed

130 low frequency sound, a resonance artefact or sound made independently. In the latter, no

131 mechanism of sound production has been proposed to explain this superposition of two

132 sounds, called two-voiced sounds (Brown, 2008) and this has not been described for

133 other blue whale's song types (McDonald et al., 2006).

134

135 There was no noticeable trend in the total number of SEP2 song phrases counted over

136 the study period although, overall, more phrases were counted in January (64

137 phrases/day in average) compared to February (36 phrases/day) (See Figure 3). No

138 significative difference was found between day and night in the number of phrases.

139 Although this is a short period study, these results show low but consistent acoustic

140 presence of Chilean blue whales throughout the months of January and February off Isla

141 Chañaral.

143 From the Raven Pro selection tables, we calculated the time between SEP2 phrases, i.e., 144 the inter-phrase interval (IPI), (Fig. 4). The peaks at 2 and 4 min are characteristic of 145 SEP2 individual song (Buchan, Rendell, and Hucke-Gaete, 2010) and suggest that 146 phrases could be produced by single singers rather than multiple overlapping singers. 147 There is only one instance of song phrase overlap on January 28, 2017, reflected by 148 shorter IPIs of 50-70s, which might suggest the presence of two singers. This is 149 consistent with limited opportunistic sighting observations: A single blue whale 
150 performing circular dives and fluking, consistent with foraging behavior (Buchan and

151 Quiñones, 2016), was observed by S. Buchan on February 15-17 and 23, 2017 within

152 the Chañaral Channel and to the South of Isla Chañaral; and sightings of two blue

153 whales together on January 16, 2017 (observed by J. Patris, S. Buchan, and F. Malige).

155 The number of phrases per day reported remains low compared to acoustic studies from

156 Chilean Patagonia, where over one thousand SEP2 phrases were automatically detected

157 per day between the months of March and May 2012-2013, which is thought to be the

158 time of maximum abundance of animals in this region (Hucke-Gaete, Osman, Moreno,

159 Findlay, and Ljungblad (2003), Buchan et al. (2015), Galletti-Vernazzani, Jackson,

160 Cabrera, Carlson, and Brownell Jr (2017)). Since there is not yet year-round data off Isla

161 Chañaral, it is impossible to compare seasonal trends in acoustic presence of Chilean

162 blue whales at both sites. However, sighting data off Isla Chañaral (Sepulveda et al.,

163 2017) and in Chilean Patagonia (Hucke-Gaete et al. (2013), Galletti-Vernazzani et al.

164 (2017)) still suggest much higher abundance in Chilean Patagonia, which is considered

165 the primary feeding ground for Chilean blue whales.

166 During visual inspection of the data set, no Antarctic blue whale song type (Ljungblad, 167 Clark, and Shimada (1998), Matsuoka, Murase, Nishiwaki, Fukuchi, and Shimada 168 (2000)) has been detected, although it has been recorded in the Chilean Patagonia 169 (Buchan, Hucke-Gaete, Stafford, and Clark, 2018) and also in low-latitude East Pacific 170 Ocean (Stafford et al., 2004). No SEP1 blue whale's song type (Cummings and 171 Thompson, 1971) has been detected in this data set. SEP1 has been recorded in Chilean 172 Patagonia, off Juan Fernandez Archipelago and in the East Tropical Pacific (Cummings 173 and Thompson (1971), Truong et al. (2016), Stafford et al. (1999b)) but is the least 
174 common of the two Southeast Pacific song types (Buchan et al. (2015), Saddler et al. 175 (2017)).

176

177 This is the first report of Southeast Pacific blue whale song (or any baleen whale call) in

178 the coastal waters off Northern Chile and in the Humboldt Current System. Given the 179 high levels of productivity of this system, and considering that Southeast Pacific blue 180 whales are known to migrate between wintering grounds near Galapagos and summer 181 feeding grounds in Chilean Patagonia (Hucke-Gaete et al. (2003 and 2018), Buchan et 182 al. (2015), Torres-Florez et al. (2015), Buchan and Quinones (2016)), it would make 183 sense that some animals would take advantage of the available prey in the Humboldt 184 Current System. In particular, the dense patches of Humboldt Current krill (Euphausia 185 mucronata) known to be exploited by fin whales off Isla Chañaral (Toro et al., 2016) 186 would also offer foraging opportunities for blue whales that are on their way to or from 187 their primary feeding ground in Chilean Patagonia. The presence of southeast Pacific 188 blue whales off Isla Chañaral is further evidence of the importance of this area for the 189 conservation of endangered baleen whale populations.

190

191 Acknowledgments

192 The authors thank the research program BRILAM STIC AmSud 17-STIC-01. S.J.B. 193 acknowledges support from the Centro de Estudios Avanzados en Zonas Aridas 194 (CEAZA) (CONICYT Programa Regional Grant R16A10003) and the Center for 195 Oceanographic Research COPAS Sur-Austral (CONICYT PIA Grant AFB170006). J.P 196 and F.M. thank SABIOD MI CNRS, EADM MaDICS CNRS, and ANR-18-CE40-0014 197 SMILES for supporting this research. Finally, the authors are very grateful to Cesar 
198 Villarroel and all the divers of Explorasub diving center (Chile), Eutropia NGO (Chile)

199 and the Agrupación turística Chañaral de Aceituno (Chile).

\section{REFERENCES}

202 Balcazar, N. E., Klinck, H., Nieukirk, S. L., Mellinger, D. K., Klinck, K., Dziak R. P. 203 and Rogers, T. L. (2017) Using calls as an indicator for Antarctic blue whale occurrence 204 and distribution across the southwest Pacific and Southeast Indian Oceans. Marine 205 Mammal Science,33,172-186.

207 Bioacoustic Research Program. (2012) Raven Pro: Interactive Sound Analysis Software 208 (version 1.5) [Computer Software]. Ithaca, NY: The Cornell Lab of Ornithology. 209 Available from: http://www.birds.cornell.edu/raven.

211 Brown, J. C. (2008). Mathematics of pulsed vocalizations with application to killer 212 whale biphonation, Journal of the Acoustical Society of America 123(5), 28752883.

214 Buchan, S.J., Rendell L.E. and Hucke-Gaete R., Preliminary recordings of blue whale 215 (Balaenoptera musculus) vocalizations in the Gulf of Corcovado, northern Patagonia, 216 Chile (2010), Marine Mammal Science, 26(2), 451-459

218 Buchan, S. J., Hucke-Gaete, R., Rendell, L. E. and Stafford, K. M. (2014). A new song 219 recorded from blue whales in the Corcovado Gulf, Southern Chile, and an acoustic link 220 to the Eastern Tropical Pacific. Endangered Species Research 23,241-252. 
222 Buchan, S. J., Hucke-Gaete, R., Rendell, L. E. and Stafford, K. M. (2015). Seasonal

223 occurrence of Southeast Pacific blue whale songs in southern Chile and the eastern

224 tropical Pacific. Marine Mammal Science 31,440-458. NOTES 227

225

226 Buchan, S. J., and Quiñones, R. A. (2016). First insights into the oceanographic 227 characteristics of a blue whale feeding ground in northern Patagonia, Chile. Marine 228 Ecology Progress Series 554,183-199.

230 Buchan, S.J., Stafford, K., Hucke-Gaete, R., Clark, C.W., Balcazar-Cabrera, N., 231 Gutierrez, L., Patris, J., Malige, F., Neira, S., Sepulveda, M., Santos-Carvallo, M., and 232 Olavarría, C. (2017). A review of blue and fin whale acoustically-inferred seasonal 233 movements in the eastern South Pacific, Poster in the Society for Marine Mammalogy's 234 22nd Biennial Conference on the Biology of Marine Mammals.

236 Buchan, S.J., Hucke-Gaete, R., Stafford, K.M., and Clark, C.W. (2018). Occasional 237 acoustic presence of Antarctic blue whales on a feeding ground in southern Chile. 238 Marine Mammal Science 34(1),220-228.

240 Capella, J., Vilina, Y., and Gibbons, J. (1999). Observación de cetáceos en laisla 241 Chañaral y nuevo registros para el área de la reserva nacional Pinguino de Humboldt, 242 norte de Chile, observación of cetaceans at Isla Chañaral and new records at the 243 Humboldt Penguin national reserve, northern Chile. Estudios Oceanologicos 18, 5724464. 
246 Cerchio, S., Jacobsen, J.K., and Norris, T.F. (2001). Temporal and geographical 247 variation in songs of humpback whales, Megaptera novaeangliae : synchronous change

248 in Hawaiian and Mexican breeding assemblages. Animal behaviour, 62, 313-329

250 Cummings, W.C., and Thompson, P.O. (1971). Underwater sounds from the blue whale, 251 Balaenoptera musculus. Journal of the Acoustical Society of America 50,1193-1198.

253 Eaton, J.W., Bateman, D., and Hauberg, S. (2009). GNU Octave version 3.0.1 manual: 254 a high-level interactive language for numerical computations (CreateSpace Independent 255 Publishing $\quad$ Platform, 2009). Available from 256 http://www.gnu.org/software/octave/doc/interpreter, 11ISBN 1441413006.

258 Galletti-Vernazzani, B., Carlson, C.A., Cabrera, E. and Brownell Jr, R.L. (2012). 259 Chilean blue whales off Isla Grande de Chiloe, 2004-2010: distribution, site-fidelity and 260 behavior. Journal of Cetacean Research and Management 12, 353-360.

262 Galletti-Vernazzani, B., Jackson, J.A., Cabrera, E., Carlson, C.A. and Brownell Jr, R.L. 263 (2017). Estimates of abundance and trend of Chilean blue whales off Isla de Chiloé, 264 Chile. PLOS ONE 12(1), e0168646.

266 Gavrilov, A. N., McCauley, R.D. and Gedamke, J. (2012). Steady inter and intra-annual 267 decrease in the vocalization frequency of Antarctic blue whales. Journal of the 268 Acoustical Society of America 131, 4476-4480. 
270 Hucke-Gaete, R., Osman, L.P, Moreno, C.A., Findlay K.P. and Ljungblad, D.K. (2003).

271 Discovery of a blue whale feeding and nursing ground in southern Chile. Proceedings

272 of the Royal Society London B (Supplement) 271, S170-S174.

273

274 Hucke-Gaete, R. (2004). Distribución, preferencia de hábitat y dinámica espacial de la 275 ballena azul en Chile: 1997-2004 [Distribution, habitat preference and spatial dynamics 276 of the blue whale in Chile: 1997-2004]. Ph.D. thesis, Universidad Austral de Chile, 277 Valdivia, Chile.

278

279 Hucke-Gaete, R., Haro, D., Torres-Florez, J., Montecinos, Y., Viddi, F., Bedriñana280 Romano, L., Nery, M. and Ruiz, J. (2013). A historical feeding ground for humpback 281 whales in the eastern South Pacific revisited: The case of Northern Patagonia, Chile. 282 Aquatic Conservation Marine and Freshwater Ecosystems. 23. 10.1002/aqc.2343.

284 Hucke-Gaete, R., Bedriñana-Romano, L., Viddi, F.A., Ruiz, J.E., Torres-Florez, J.P. and 285 Zerbini, A.N. (2018). From Chilean Patagonia to Galapagos, Ecuador : novel insights on 286 blue whale migratory pathways along the Eastern South Pacific. PeerJ 6, e4695, 287

288 Ljungblad, D. K., Clark, C.W. and Shimada, H. (1998). A comparison of sounds 289 attributed to pygmy blue whales (Balaenoptera musculus brevicauda) recorded south of 290 the Madagascar Plateau and those attributed to 'true' blue whales (Balaenoptera 291 musculus) recorded off Antarctica. Report of the International Whaling Commission 48, $292 \quad 439-442$. 
294 Matsuoka, K., Murase, H., Nishiwaki, S., Fukuchi, T. and Shimada, H. 2000.

295 Development of a retrievable sonobuoy system for whale sounds recording in polar 296 region. Paper SC/52/O7 presented to the IWC Scientific Committee, (2000), in Adelaide, 297 Australia (unpublished).

298

299 McDonald, M. A., Mesnick, S.L. and Hildebrand, J.A. (2006). Biogeographic 300 characterisation of blue whale song worldwide: Using song to identify populations. 301 Journal of Cetacean Research Management 8, 55-56.

303 McDonald, M. A., Hildebrand, J.A. and Mesnick, S. (2009). Worldwide decline in tonal 304 frequencies of blue whale songs. Endangered Species Research 9, 13-21.

305

306 Mellinger, D.K., Stafford K.M., Moore S.E., Dziak R.P. and Matsumoto H. (2007) An 307 overview of fixed passive acoustic observation methods for cetaceans. Oceanography. 308 20(4), 36-45.

310 Mullen, K.A., Peterson,M.L., and Todd, S.K. (2013) Has Designating and Protecting 311 Critical Habitat Had an Impact on Endangered North Atlantic Right Whale Ship Strike 312 Mortality? Marine Policy 42, 293-304.

314 Oleson, E. M., Calambokidis, J., Burgess, W.C., McDonald, M.A., LeDuc, C.A. and 315 Hildebrand, J.A. (2007a). Behavioural context of call production by eastern North 316 Pacific blue whales. Marine Ecology Progress Series 330, 269-284. 
318 Oleson, E. M., Wiggins, S.M. and Hildebrand, J.A. (2007b). Temporal separation of 319 blue whale call types on a southern California feeding ground. Animal Behaviour 74, $320881-894$.

322 Piñones, A. and Fedorov, A.V. (2016). Projected changes of Antarctic krill habitat by the 323 end of the 21st century. Geophysical Research Letters 43, 8580-8589.228

325 Patris, J., Malige, F., and Glotin, H. (2017). Construction et mise en place d'un système 326 fixe d’enregistrement à large bande pour les cétacés “bombyx 2” isla de chañaral, été 327 austral 2017. Technical Report 2017-03, LSIS CNRS.

329 Patris, J. (2019). Contribution en méthodes pour le suivi de mysticètes par acoustique 330 passive, $P h D$ thesis, Université de Toulon, France. Avaiblable from 331 http://www.theses.fr/2019TOUL0016

333 Patris, J., Malige, F., Glotin, H., Asch, M. and Buchan, S. (2019). A standardized 334 method of classifying pulsed sounds and its application to pulse rate measurement of 335 blue whale southeast Pacific song units. The Journal of the Acoustical Society of 336 America. 146, 2145-2154.

338 Perez-Alvarez, M., Thomas, F., Uribe, F., Sepúlveda, M., Flores, M. and Moraga, R. 339 (2006). Fin Whales (Balaenoptera physalus) Feeding on Euphausia mucronata in 340 Nearshore Waters off North-Central Chile. Aquatic Mammals. 32, 109-113. 
342 Pompa, S., Ehrlich, P.R., and Ceballos G. (2011). Global Distribution and Conservation

343 of Marine Mammals. Proceedings of the National Academy of Sciences of the United

344 States of America 108 (33), 13, 600-605.

346 Redfern, J.V., McKenna, M.F., Moore, T.J., Calambokidis, J., Deangelis, M.L., Becker, 347 E.A., Barlow, J., Forney, K.A., Fiedler, P.C., and Chivers, S.J. (2013a) Assessing the 348 Risk of Ships Striking Large Whales in Marine Spatial Planning. Conservation Biology 34927 (2), 292-302.

351 Redfern, J.V., Hatch, L.T., Caldow, C., DeAngelis, M.L., Gedamke, J., Hastings, S., 352 Henderson, L., McKenna, M.F., Moore, T.J., and Porter, M.B. (2013b). Assessing the 353 risk of chronic shipping noise to baleen whales off Southern California, USA. 354 Endangered Species Research. 32, 53-167.

356 Saddler, M.R., Bocconcelli, A., Hickmott, L.S., Chiang, G., Landea-Briones, R., 357 Bahamonde, P.A., Howes, G., Segre, P.S. and Sayigh, L.S. (2017) Characterizing 358 Chilean blue whale vocalizations with DTAGs: a test of using tag accelerometers for 359 caller identification, Journal of Experimental Biology (220), 4119-4129

361 Samaran, F., Stafford, K.M., Branch, T.A., Gedamke, J., Royer, J.R., Dziak, R.P. and 362 Guinet, C. (2013). Seasonal and geographic variation of the southern blue whale 363 subspecies in the Indian Ocean. PIOS ONE 8(8), 1-10. 
365 Sepúlveda, M., Santos, M. and Pavez, G. (2017). Whale-watching en la Reserva Marina 366 Isla Chañaral: Manejo y planificación para una actividad sustentable. Primera Edición 367 2017, ISBN: 978-956-368-225-0

368

369 Sepúlveda, M., Pérez-Álvarez, M.J., and Santos-Carvallo, M. (2018) From whaling to 370 whale watching: Identifying fin whale critical foraging habitats off the Chilean coast. 371 Aquatic Conservation Marine and Freshwater Ecosystems 018, 1-9.

373 Širović, A., Hildebrand, J. A., Wiggins, S.M. and Thiele, D. (2009). Blue and fin whale 374 acoustic presence around Antarctica during 2003 and 2004. Marine Mammal Science $37525,125-136$.

376

377 Stafford, K. M., Nieukirk, S.L. and Fox, C.G. (1999a). An acoustic link between blue 378 whales in the eastern tropical Pacific and the northeast Pacific. Marine Mammal 379 Science 15, 1258-1268.

380

381 Stafford, K. M., Nieukirk, S.L. and Fox, C.G. (1999b). Low-frequency whale sounds 382 recorded on hydrophones moored in the eastern tropical Pacific. Journal of the 383 Acoustical Society of America 106, 3687-3698.

385 Stafford, K. M., Nieukirk, S.L. and Fox, C.G. (2001). Geographical and seasonal 386 variation of blue whale calls of the North Pacific. Journal of Cetacean Research 387 Management 3, 65-76. 
389 Stafford, K. M., Bohnenstiehl, D. , Tolstoy, M., Chapp, E.,Mellinger, D. and Moore, S. 390 (2004). Antarctic-type blue whale calls recorded at low latitudes in the Indian and 391 eastern Pacific Oceans. Deep Sea Research Part I: Oceanographic Research Papers. 392 51. 1337-1346. 10.1016/j.dsr.2004.05.007.

394 Stafford, K. M., Chapp, E., Bohnenstiel, D.R and Tolstoy M.. (2011). Seasonal detection 395 of three types of "pygmy" blue whale calls in the Indian Ocean. Marine Mammal 396 Science 27, 828-840.

398 Thiel, M., Macaya, E., Acuna, E., Arntz, W., Bastias, H., Brokordt, K., Camus, P., 399 Carlos Castilla, J., Castro, L., Cortes, M., Dumont, C., Escribano, R., Fernandez, M., 400 Gajardo, J.A., Gaymer, C., Gomez, I., Gonzalez, A.E., González, H.E, Haye, P. and 401 Vega, A. (2007). The Humboldt Current System of Northern and Central Chile. 402 Oceanography and marine biology. 45, 195-345

403

404 Toro, F., Vilina, Y.A., Capella, J. and Gibbons, J. (2016) Novel Coastal Feeding Area 405 for Eastern South Pacific Fin Whales (Balaenoptera physalus) in Mid-Latitude 406 Humboldt Current Waters off Chile, Aquatic Mammals 42(1), 47-55.

407

408 Torres-Florez, J.P., Hucke Gaete, R., and LeDuc, R. (2014). Blue whale population 409 structure along the eastern South Pacific Ocean: Evidence of more than one population. 410 Molecular Ecology 23(24), 5998-6010. 
411 Torres-Florez, J.P., Olson, P.A., Bedriñana-Romano, L., Rosenbaum, H.C.R., Ruiz, J., 412 LeDuc, R. and Hucke Gaete, R. (2015) First documented migratory destination for 413 eastern South Pacific blue whale. Marine Mammal Science, 31(4), 1580-1586

414

415 Truong, G., Širović, A., Tripovich, J., and Rogers, T. (2016). Seasonal patterns in 416 Chilean blue whale call detections between 2003 and 2015. SC/66b/SH/25, 417 International Whaling Commission.

418

419 Van Parijs, S.M., Clark, C.W., Sousa-Lima, R.S., Parks, S.E., Rankin, S., Risch, D.,and 420 Van Opzeeland, I.C. (2009). Management and research applications of real-time and 421 archival passive acoustic sensorsover varying temporal and spatial scales. Marine 422 Ecology Progress Series 395, 21-36.

423

424

425

426

427

428

429

430

431

432

433

434

435 


\section{Figure captions and captions}
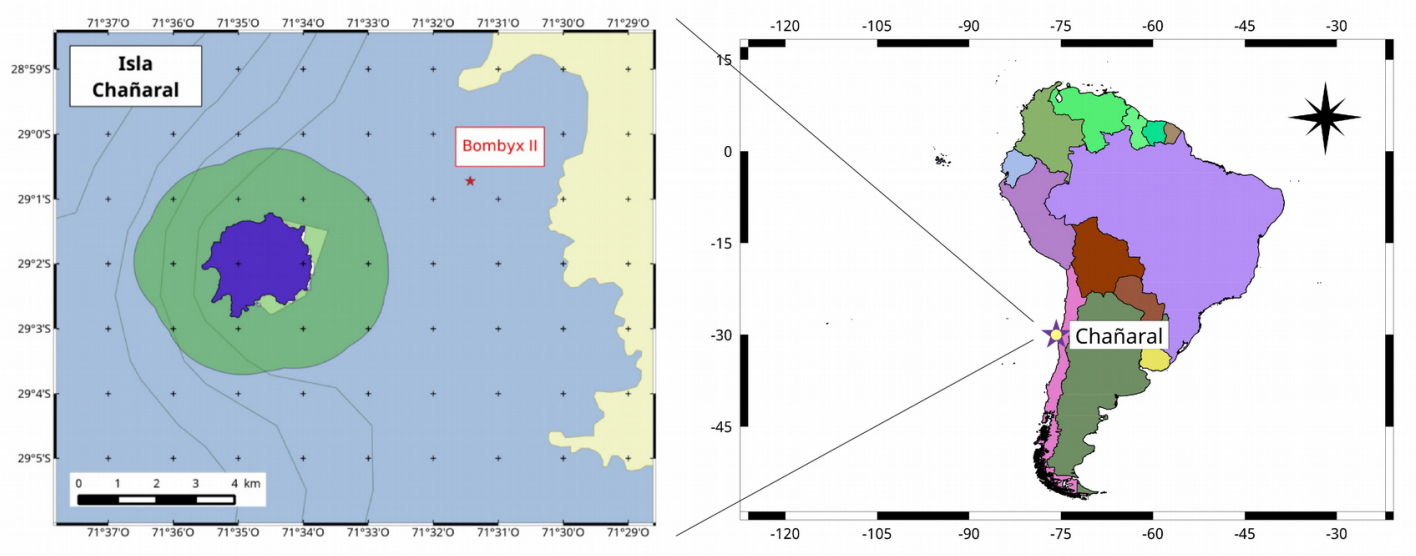

450 Figure 1. Map of the deployment zone of the BOMBYX II device (left). The green zone

451 around the Island is a marine protected area (Reserva Marina Isla Chañaral). General

452 location in South America (right).

453 


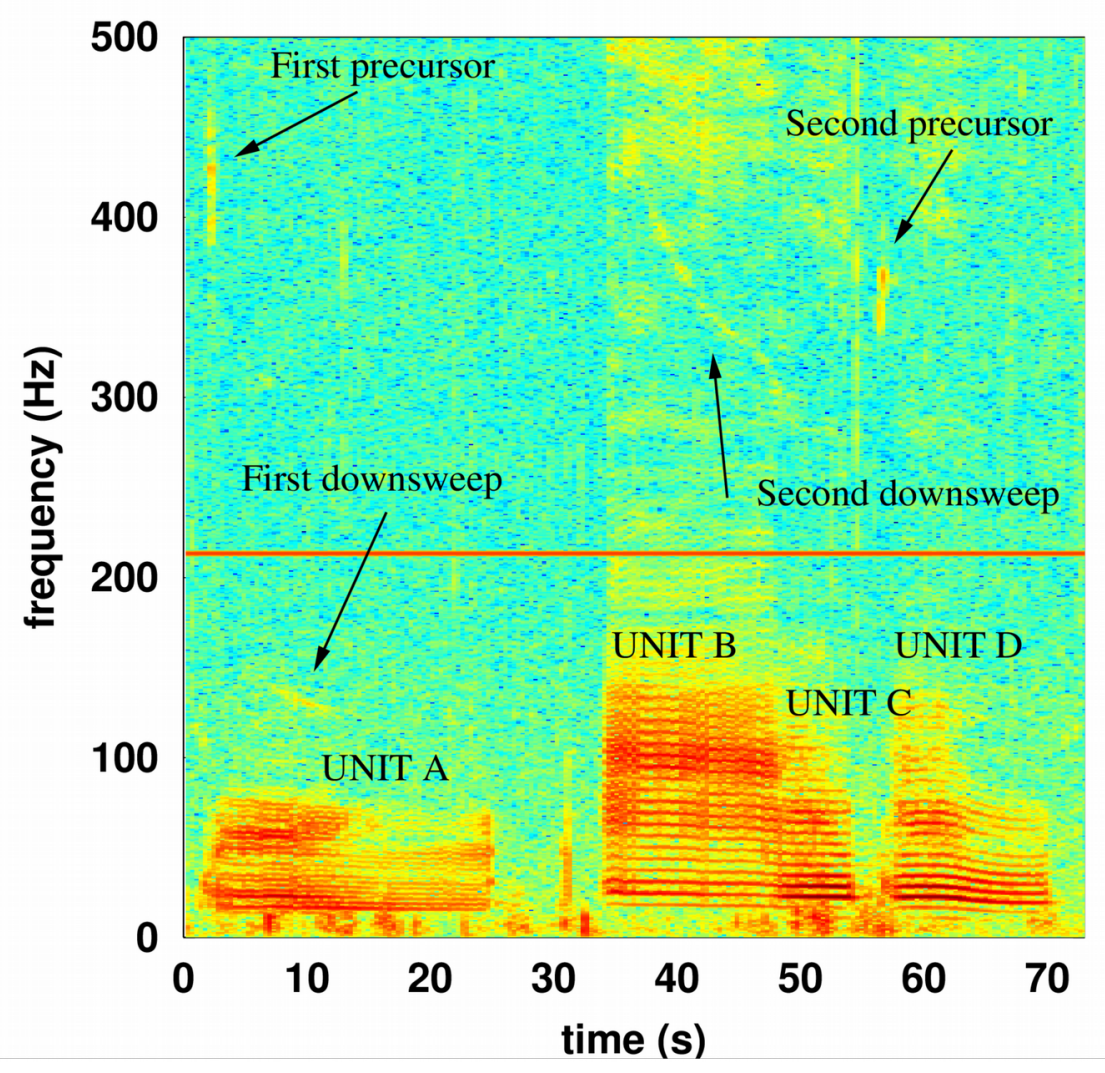

459 Figure 2. Time frequency representation of a SEP2 song recorded off Isla Chañaral, on 460 February 2, 2017 (Fast Fourier transform, Blackman window of 65,536 points, 461 overlapping 75\%) using Octave software (Eaton, Bateman, and Hauberg, 2009). The 462 line at $213 \mathrm{~Hz}$ is a constant electronic noise coming from the coupling between the 463 hydrophone and the recording device. Units A, B, C, D are clearly visible as well as 464 precursors and downsweeps belonging to the song.

465 


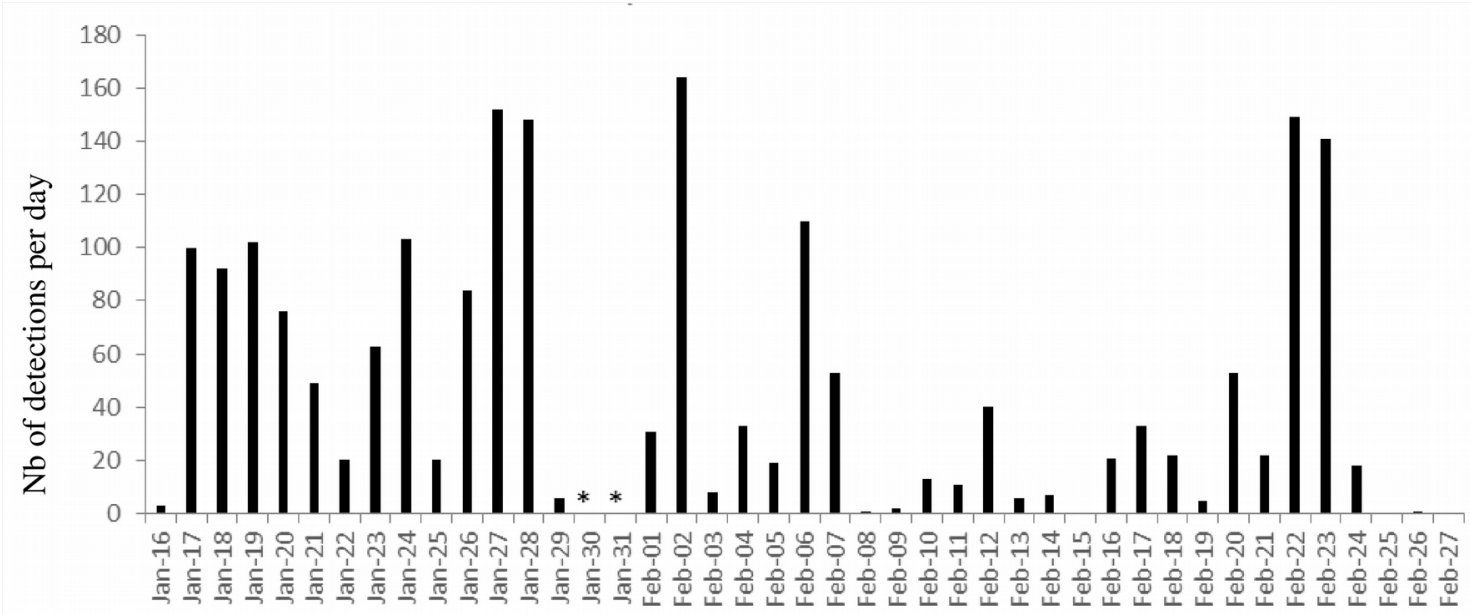

473 Figure 3. Number of SEP2 phrases counted in the first season of recording off Isla 474 Chañaral. The device was off duty during January 30 and 31 (asterisks) and the 475 February 13 and 14.

476 477 478 479 480 481 482 
Time intervals

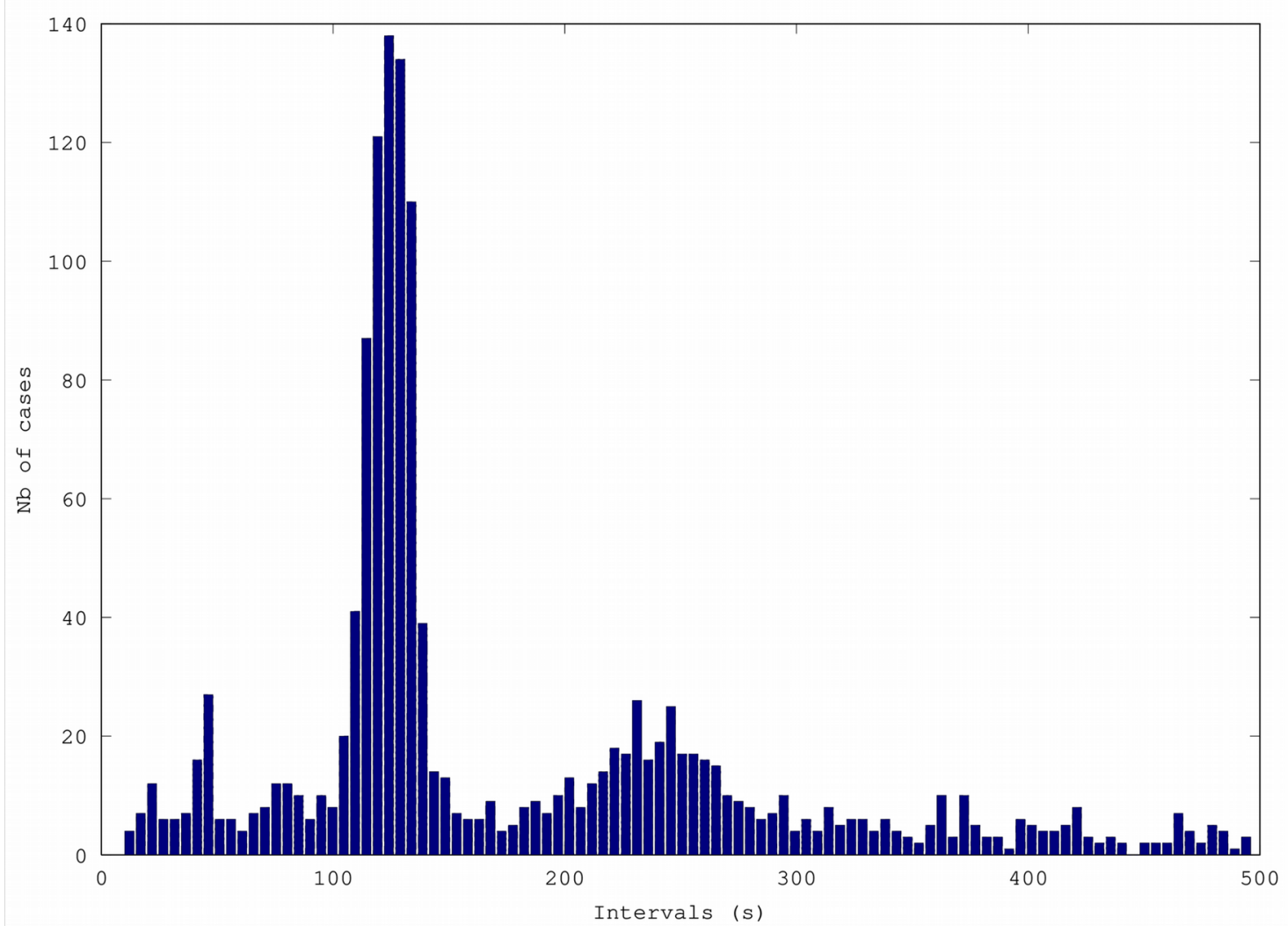

484 Figure 4. Histogram of the inter-phrase intervals (IPIs) between two occurrences of 485 SEP2 phrases, from the Raven Pro selection table.

486

487

488

489

490

491 
1 i During the analysis, other vocalizations were found: blue whale "D-calls", fin whale

2 (Balaenoptera physalus) vocalizations, bottlenose dolphins' (Tursiops truncatus) echolocation

3 clicks, whistles and low-frequency vocalizations, and dusky dolphin (Lagenorhynchus obscurus)

4 burst of pulses (see Patris, 2019). This dataset can be obtained asking the authors. 